\title{
Summary of Hydrologic Conditions in Kansas, Water Year 2016
}

\section{By Justin M. Louen}

The U.S. Geological Survey (USGS), in cooperation with Federal, State, and local agencies, maintains a long-term network of hydrologic monitoring sites in Kansas. Real-time data are collected at 216 streamgage sites and are verified throughout the year with regular measurements of streamflow made by USGS personnel. Annual assessments of hydrologic conditions are made by comparing statistical analyses of current and historical water year (WY) data for the period of record. A WY is the 12-month period from October 1 through September 30 and is designated by the calendar year in which the period ends. Long-term monitoring of hydrologic conditions in Kansas provides critical information for water-supply management, flood forecasting, reservoir operations, irrigation scheduling, bridge and culvert design, ecological monitoring, and many other uses.

\section{Statewide Overview}

The streamflow and basin runoff conditions for Kansas were mostly normal ( 25 th-75th percentile) to above normal (76th-90th percentile) throughout the State for WY 2016

(U.S. Geological Survey, 2016a). The precipitation in Kansas was near average to above average (110-200 percent of normal) during WY 2016, with cumulative rainfall totals mostly attributed to large, periodic precipitation events during April through September 2016 (National Oceanic and Atmospheric Administration, National Climatic Data Center, 2016). Hydrologic conditions for WY 2016 reflected a continued recovery from peak drought in WY 2012, with drought conditions being nonexistent for the entire State from mid-May through mid-June for the first time since July 2010 (Miskus and National Drought Mitigation Center, 2016). Statewide runoff for WY 2016 finished just above the normal range (25th-75th percentile) of annual conditions for Kansas based on 115 years of observed record (U.S. Geological Survey, 2016a).

\section{Streamflow Conditions}

The streamflow conditions in Kansas streams were normal (25th-75th percentile) to above normal (76th-90th percentile) throughout most of WY 2016 (fig. 1; U.S. Geological Survey, 2016a). Mostly normal to below normal (10th-24th percentile) streamflow conditions were present throughout the State in the beginning of WY 2016, with much below normal (less than 10th percentile) conditions within the Solomon, Smoky Hill-Saline, Lower Arkansas, and Cimarron drainage basins in western Kansas (rivers are shown on fig. 2). Statewide streamflow conditions began to recover during the first few months of WY 2016, particularly in eastern Kansas with much above normal (greater than 90th percentile) conditions in December 2015. Widespread precipitation events through the spring brought most of the streams in the State to within normal streamflow conditions. Periodic, high-intensity precipitation events through the summer months, particularly in northwest Kansas and south-central Kansas around Wichita (cities are shown on fig. 2), elevated streamflow conditions to much above normal in these areas. Normal to above normal conditions were present throughout Kansas, with the exception of the southwest corner of the State, at the end of WY 2016 (fig. 1).

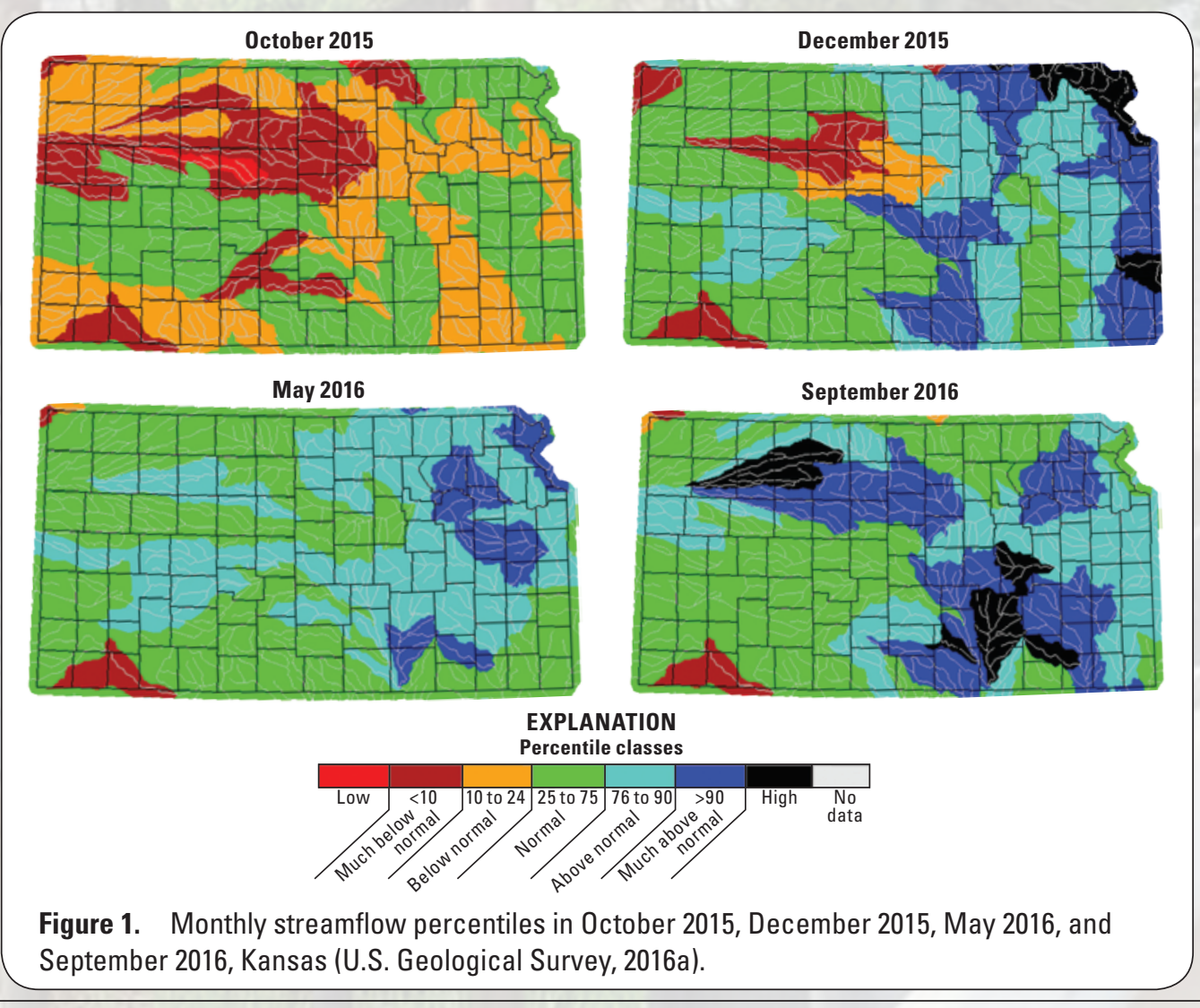


Saline River near Russell, Kansas (streamgage 06867000)

The Saline River originates in Kansas Seven-day aver strealina, remained below normal to the ent April, with cumulative streamflow tracking with the lowest (10th percentile) observed cumulative streamflow of record. Increased runoff from periodic, high-intensity precipitation events normal conditions in May. More highintensity precipitation events in Septo much above normal, with cumulative streamflow finishing above the Geological Survey, 2016a). Flooding in September 2016 resulted in the highest instantaneous peak streamflow $(19,300$ and fifth highest in 65 years of observe logical Survey, 2016b). westem Kansas and flows east and dramatically raised streamflow to above tember raised 7-day average streamflow 75th percentile to finish the WY (U.S. cubic feet per second $\left[\mathrm{ft}^{3} / \mathrm{s}\right]$ ) since 1995
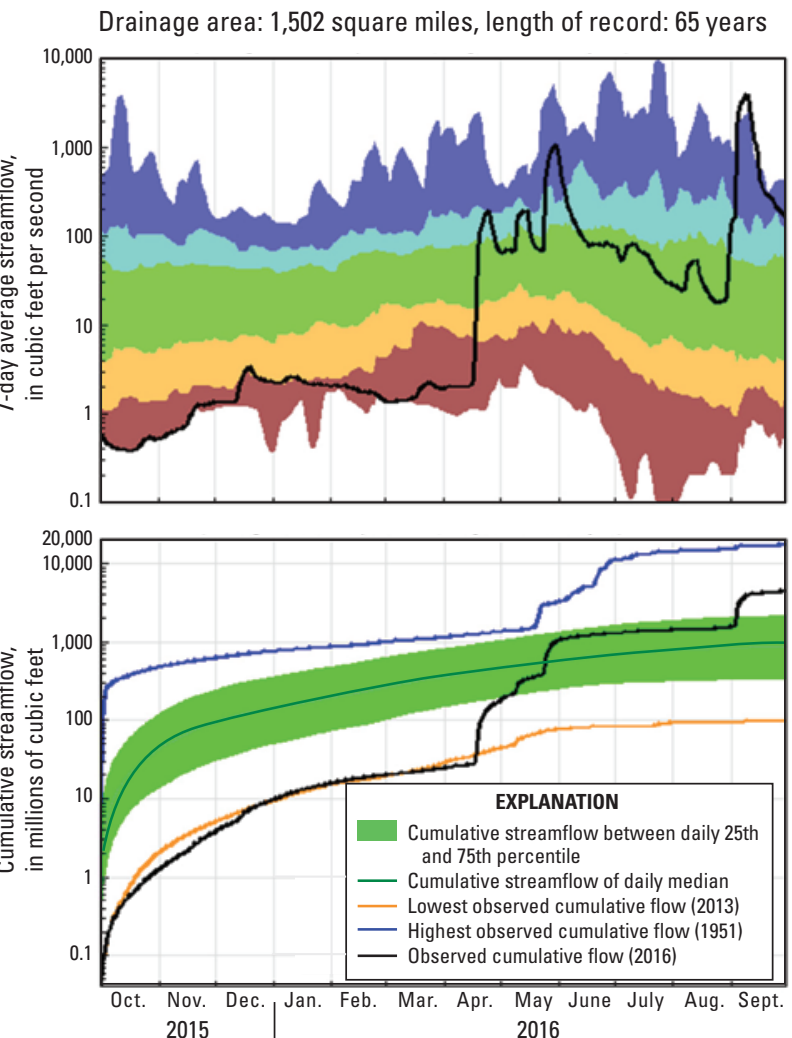

Streamflow Conditions at Selected Streamgaging Locations

Four streamgages were selected to represent streamflow conditions for WY 2016 in Kansas. Locations of the selected streamgage are representative of the spatial and temporal varibility of conditions present in different regions of the State (fig. 2).

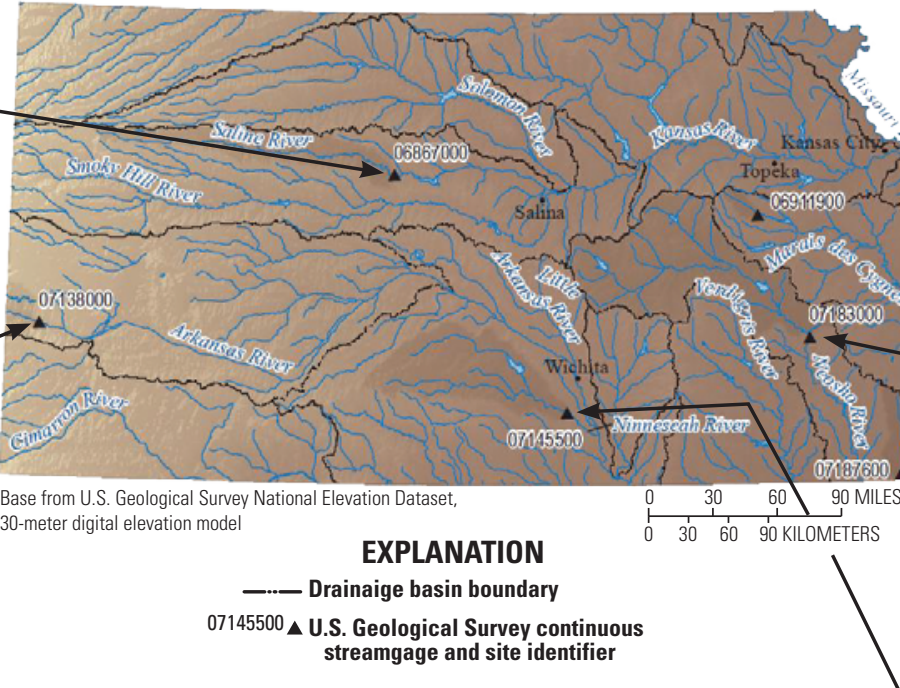

Figure 2. Locations of selected U.S. Geological Survey streamgages, water year 2016, Kansas.

7-day average streamflow

XPLANATION (graphs

Hydrographs display the 7-day average streamflow in cubic feet per second
for water year 2016 compared to the observed historical 7 -day average flows for a iven streamigage's entire record. Data range from much below normal (less than the loth percentiley to muac
logical Survey, 2016a)
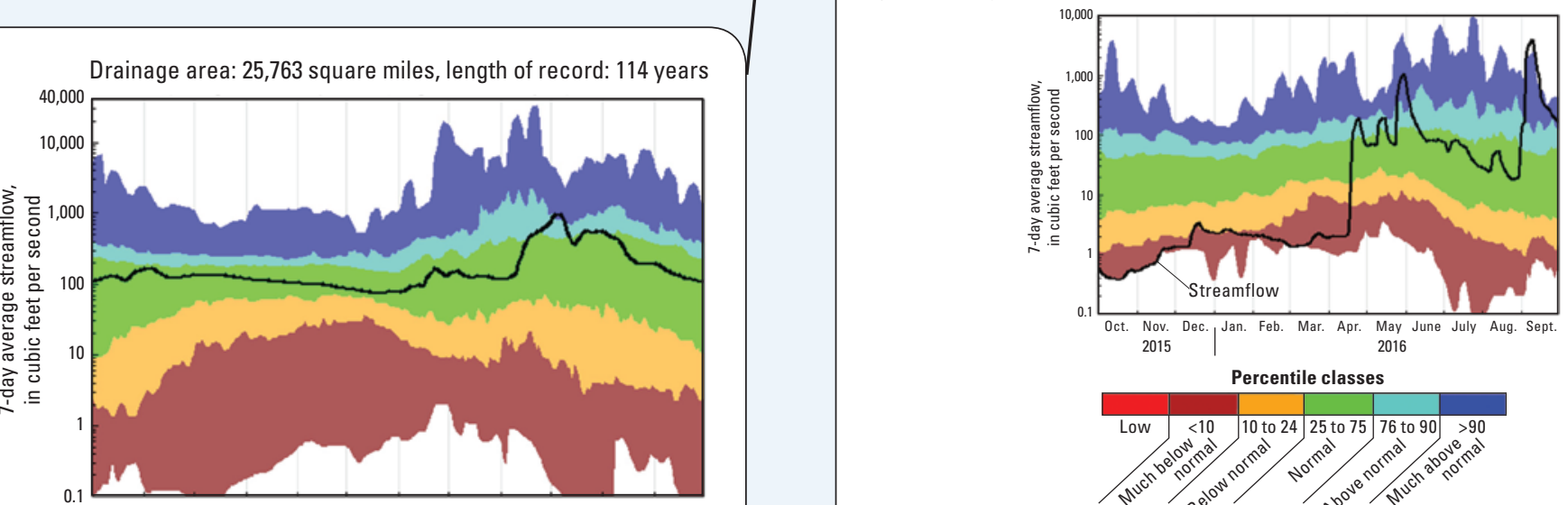

\section{Arkansas River at Syracuse, Kansas}

(streamgage 07138000)

The Arkansas River originates in Colorado and flows through wester and south-central Kansas into Okladiverted for irrigation in wester Kansas and for flood cons a Wichita, Kans. Seven-day averge streamflow was mostly within the normal range of historical record for alt of WY 2016. Cumulative streamflow for WY 2016 improved dramatically from WY 2013, which had the lowest observed cumulative flow in 99 years of record (U.S. Geological Survey, 2016a). Average annual streamflow for WY 2016 was $198.1 \mathrm{ft}^{3} / \mathrm{s}$ compared to just $2.76 \mathrm{ft} / \mathrm{s}$ for WY 2013 during drought conditions (U.S. Geological

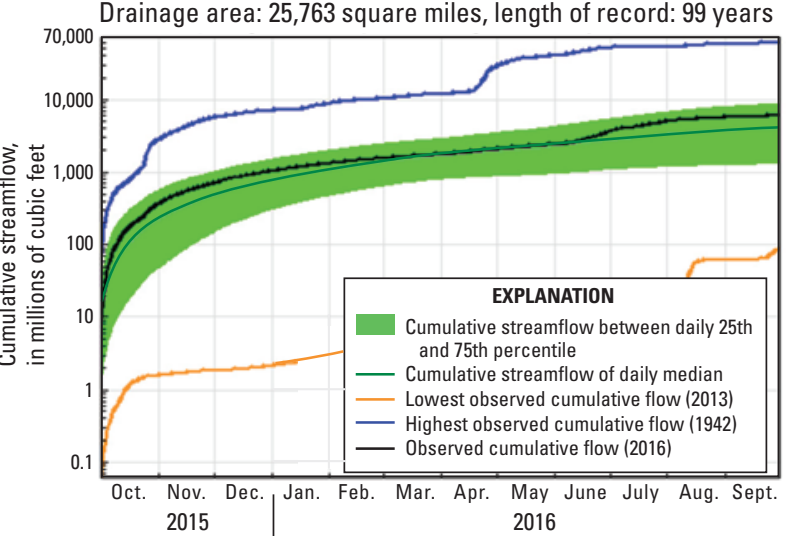

Neosho River near lola, Kansas (streamgage 07183000)

The Neosho River originates in east-central Kansas and flows flow is regulated by reservirs in upper part of the drainage basin with numerous tributaries present throughout its watercourse. Seven-day average streamflow was mostly normal or above normal throughout WY 2016. High-intensity precipitation events September 2016, including increased reservoir outflows, raised 7-day average streamflow to much above normal to finish the WY. Cumulative streamflow was at or above the 75th percentile of 104 years of record at this streamgage for much of WY 2016 (U.S. Geological Survey, 2016a)
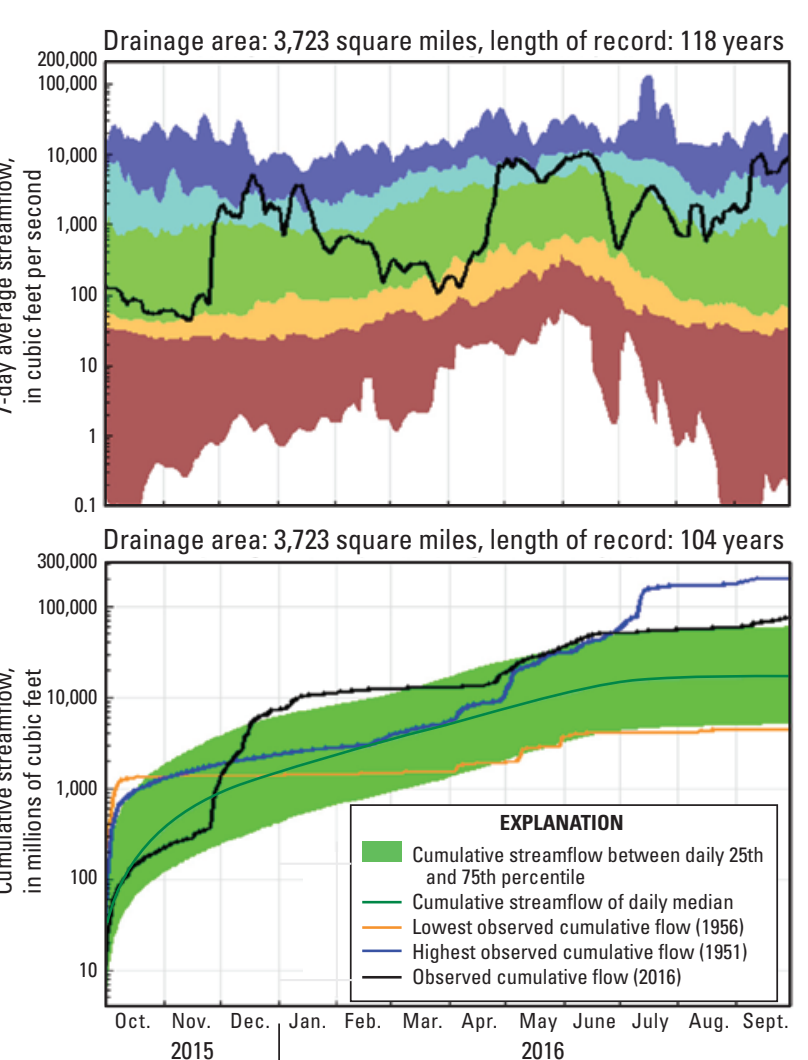
of record and highest since 1923

\section{Ninnescah River near Peck, Kansas} (streamgage 07145500)

The Ninnescah River is a tribuary of the Arkansas River in southcentral Kansas. Seven-day average strant for condilions typically (n) bew nor in October and November 2015, (U.S. Geological Survey, 2016a) There was major flooding in the Ninnescah River in September 2016, with the second highest peak instantaneous flow $\left(40,300 \mathrm{ft}^{3} / \mathrm{s}\right)$ in 78 ye (U.S. Geological Survey, 2016b). Cumulative annual streamflow for WY 2016 finished above the 75th percentile of record at this streamgage for the first time since 2010 .

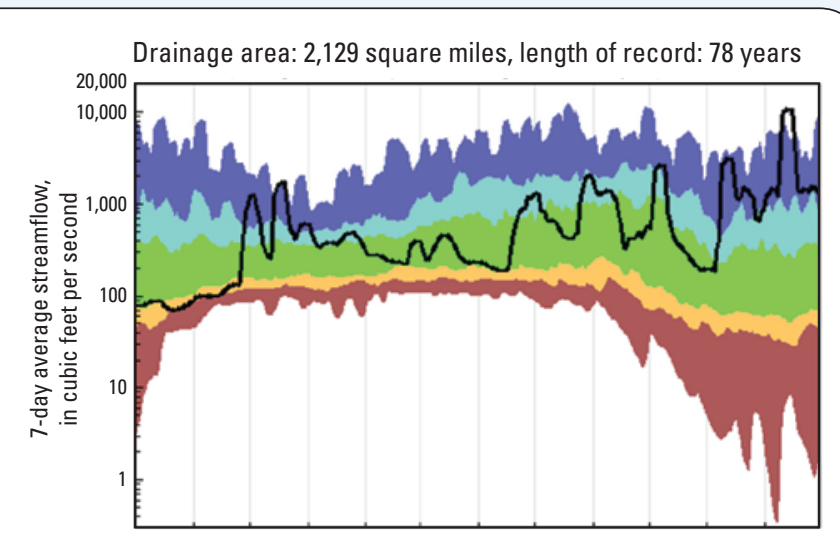

Hydrographs display the cumulative streamflow in millions of cubic feet for centile range of annual cumulative streamflow for a given streamgage's entire record
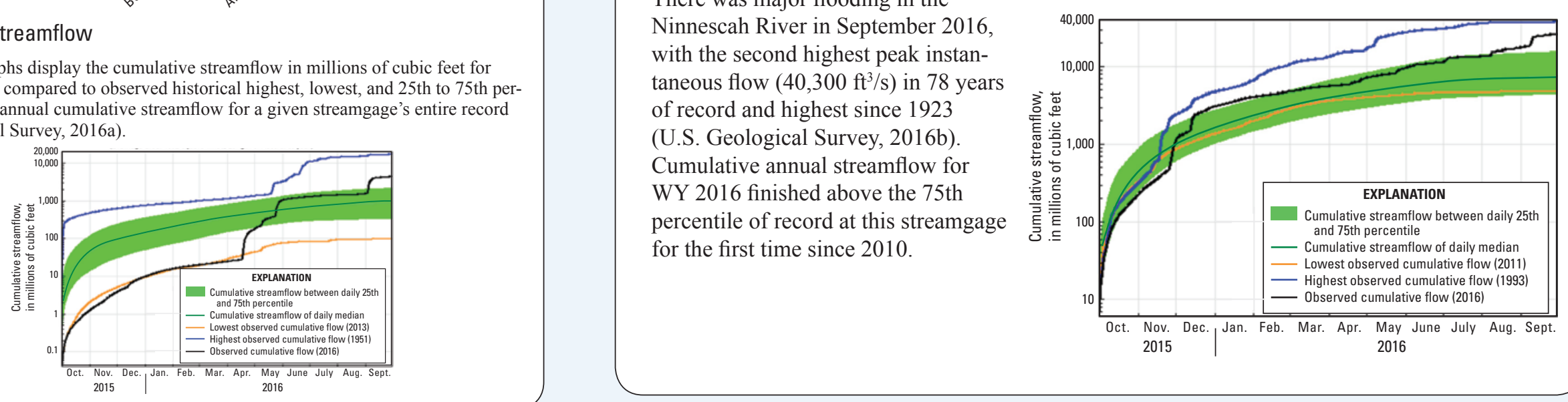


\section{Drainage Basin Runoff}

Runoff, or streamflow per unit area, is calculated for each drainage basin and displayed as a percentile range uniformly over the entire drainage area. Runoff is a good indicator of precipitation and streamflow conditions for a given drainage basin and is not solely dependent on precipitation inputs for an area because groundwater recharge and storage in reservoirs can prevent water from leaving a drainage basin (Langbein and Iseri, 1960).

Mostly normal statewide runoff conditions persisted throughout WY 2016, with some areas of the State finishing the WY with much above normal conditions (fig. 3; U.S. Geological Survey, 2016a). Eastern and central Kansas had mostly normal runoff conditions, with above normal and much above normal conditions in areas that received high-intensity precipitation during all four quarters. Runoff conditions in western Kansas improved during the latter half of WY 2016, changing in some areas from much below normal levels through March 2016 to above normal conditions by September 2016. Statewide runoff for WY 2016 (3.99 inches) finished just above the 75th percentile (3.92 inches) and had an average recurrence interval of 4.5 years based on 115 years of record (fig. 4; U.S. Geological Survey, 2016a). Improved runoff conditions were particularly notable in western Kansas compared to conditions observed for WY 2014 and WY 2015 despite above average annual precipitation observed during those water years (U.S. Geological Survey, 2016a; National Oceanic and Atmospheric Administration, National Climatic Data Center, 2016). Runoff for WY 2016 followed the trend of recovery to either normal or above normal levels following periodic, consecutive years of drought conditions observed during the previous 115 years of record.

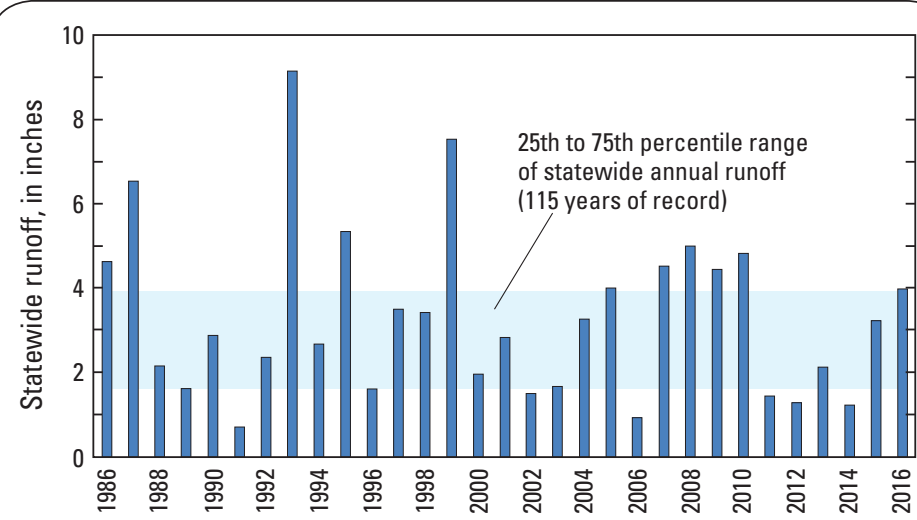

Figure 4. Annual statewide runoff for water years 1986-2016 with 25th to 75th percentile range based on 115 years of record (U.S. Geological Survey, 2016a).

\section{References Cited}

Langbein, W.B., and Iseri, K.T., 1960, General introduction and hydrologic definitions: U.S. Geological Survey Water-Supply Paper 1541-A, 29 p.

Miskus, David, and National Drought Mitigation Center, 2016, U.S. Drought Monitor-Kansas: National Drought Mitigation Center, U.S. Drought Monitor Web page, accessed November 11, 2016, at http://droughtmonitor.unl.edu/.

National Oceanic and Atmospheric Administration, National Climatic Data Center, 2016, National temperature and precipitation maps: accessed November 11, 2016, at http://www.ncdc. noaa.gov/temp-and-precip/maps.php.
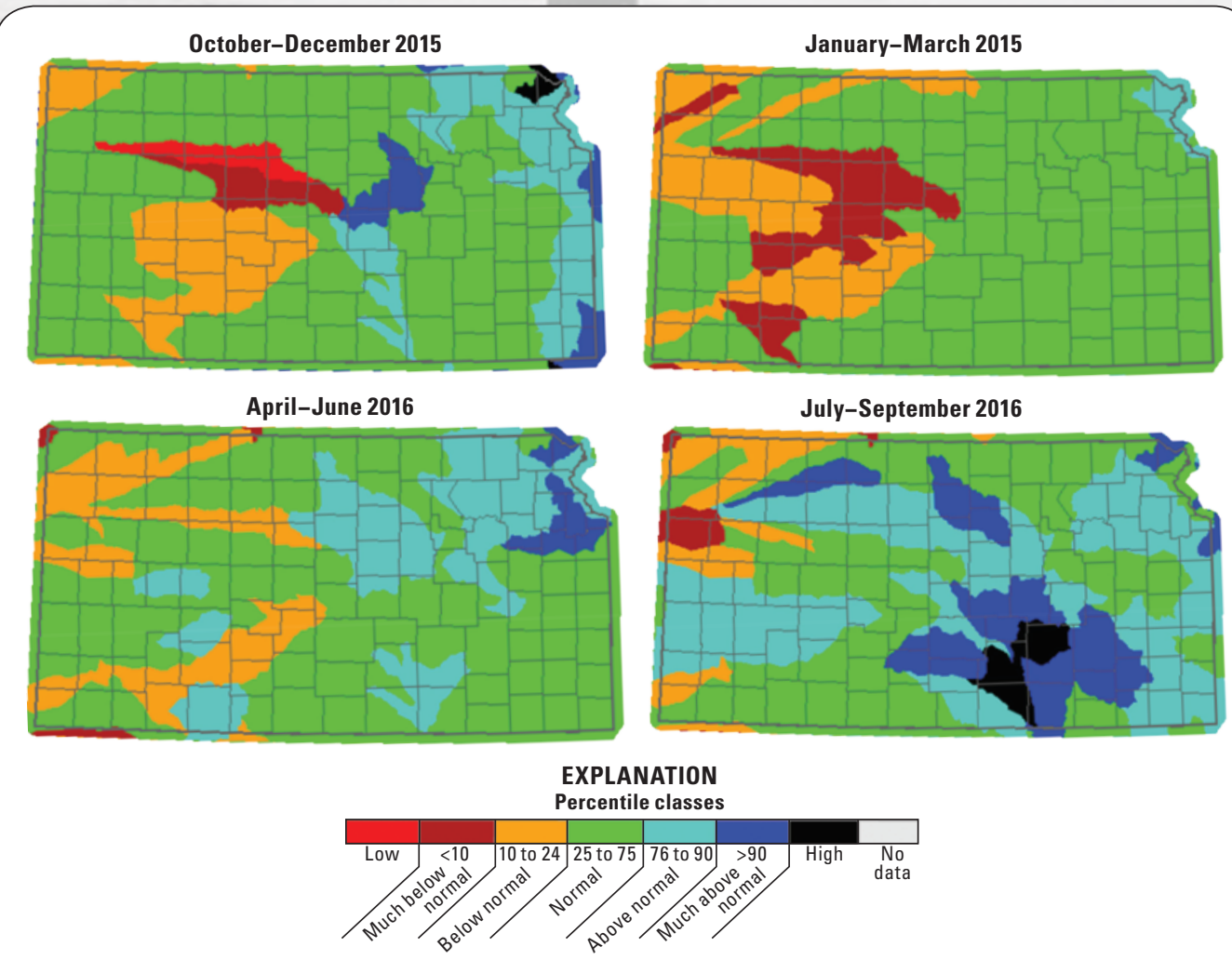

Figure 3. Quarterly runoff percentiles for water year 2016, Kansas (U.S. Geological Survey, 2016a).
U.S. Geological Survey, 2016a, WaterWatch-Current water resources in Kansas: accessed November 10 , 2016, at https://waterwatch.usgs.gov/.

U.S. Geological Survey, 2016b, National Water Information System-Web interface: U.S. Geological Survey database, accessed November 10, 2016, at https://waterdata.usgs. gov/nwis/.

For additional information concerning this publication, contact:

Director, USGS Kansas Water Science Center:

4821 Quail Crest Place

Lawrence, KS 66049

(785) 842-9909

Or visit the Kansas Water Science Center website at:

https://ks.water.usgs.gov

ISSN 2327-6932 (online) ISSN 2327-6916 (print) https://doi.org/10.3133/fs20173020 